\title{
VULNERABILITY OF THE SOILS OF METROPOLITAN LIMA AND THEIR RELATIONSHIP WITH URBAN SUSTAINABILITY
}

Raúl Méndez Gutiérrez

National University Federico Villarreal, (Peru). E-mail: rmendez@unfv.edu.pe ORCID: https://orcid.org/0000-0001-5644-483X

Doris Esenarro Vargas

National University Federico Villarreal, (Peru). E-mail: desenarro@unfv.edu.pe ORCID: https://orcid.org/0000-0002-7186-9614

Pedro Amaya Pingo

National University Federico Villarreal, (Peru). E-mail: pamaya@unfv.edu.pe ORCID: https://orcid.org/0000-0001-9123-0124

Ciro Rodriguez Rodriguez

National University Mayor de San Marcos, (Peru). E-mail: crodriguezro@unmsm.edu.pe ORCID: https://orcid.org/0000-0003-2112-1349

\section{Citación sugerida Suggested citation}

Méndez, R., Esenarro, D., Amaya, P., y Rodriguez, C. (2020). Vulnerability of the soils of Metropolitan Lima and their relationship with urban sustainability. 3C Tecnología. Glosas de innovación aplicadas a la pyme. Edición Especial, Noviembre 2020, 161-177. https://doi.org/10.17993/3ctecno.2020. specialissue6.161-177 


\section{ABSTRACT}

This research work has a great influence on the physical security of the urban infrastructure and the citizens of our capital city, that is why it is necessary to apply prevention strategies since our city is located in a very vulnerable area to seismic events, mainly huaycos, floods and landslides, settlements, landslides and other superficial mass movements, so it is necessary to have knowledge of the causes and effects of these phenomena, the different types and carrying capacity of soils in the districts of Metropolitan Lima, in order to contribute to the knowledge of the degree of vulnerability in which urban areas, marginal urban areas, human settlements are exposed. In conclusion, surveys of public servants allowed us to determine that only $55 \%$ of them know the meaning of risk and vulnerability, so $45 \%$ are totally unaware of these terms. Likewise, surveys of the general public on the lack of a prevention culture, $83 \%$ indicated that they did, hence the need to apply a course or training on disaster risk management issues at all educational levels.

\section{KEYWORDS}

Metropolitan Lima, Urban sustainability, Bearing capacity, Soil vulnerability. 


\section{INTRODUCTION}

The present work called "Management of the Vulnerability of the Soils of Metropolitan Lima and its Relationship with Urban Sustainability" has been developed considering the importance of providing real theoretical, practical and statistical knowledge of the risks of disasters resulting from the vulnerability of soils and the latent threats or hazards in our community, which due to the lack of knowledge and implementation of preventive measures have caused a high rate of deaths and injuries, affecting the physical infrastructure works and socioeconomic activities of our capital city.

Metropolitan Lima is a city that is immersed in a process of urbanization having as factors the economic, social and environmental aspects, without considering a true urban planning that allows its integral development. The process of disorderly growth conditions the factors of vulnerability in the urban space which gives rise to a risk of disasters due to the dangers of earthquakes, floods, huaycos, etc., which threatens the physical safety of the population, urban infrastructure and the socio-economic development of the city (Alvarado et al., 2020).

It is important to consider an integral approach that contemplates the factors of vulnerability of our city considering the studies of grounds where the buildings are founded (Hospitals, schools, residential buildings, houses, etc), road infrastructure, water and drainage networks, electrical and gas installations, reservoirs, etc., because it allows us to design the foundations where the civil works are going to be built considering the aspects of seismicity and others that allow a capacity of response before a seismic event of great magnitude. Knowing the vulnerability of the soils in our capital city will allow us to have a better knowledge of the risk levels in which it is found and thus give greater importance to soil studies in accordance with the National Building Regulations (Centro Nacional de Estimación, Prevención y Reducción del Riesgo de Desastres (CENEPRED), 2015).

The study of Soil Mechanics becomes a necessary and essential element through which it allows us to know the bearing capacity of soils, settlements, etc., for the purpose of building foundations in areas of urban expansion as well as in places of building renovation. In the developed work, it has been taken into account the analysis of the causes that originate the vulnerability of the soils, for which field works (Trial pits), laboratory and office are indicated, as well as statistical data of the last years, conceptualizations referring to risk, 
vulnerability and danger are discussed, for the obtaining of results taking into consideration the stratigraphic profiles, Results of the calculations of bearing capacity and settlement of soils, as well as the chemical analysis of soils in most districts of Metropolitan Lima, whose significant results show the importance of soil studies to know the resistance and response to mainly seismic and other hazards, which will allow the reduction of vulnerability and therefore mitigate the risk of future disaster events. Surveys have also been carried out in various districts of the capital in which the current situation of soil knowledge and its relationship with urban sustainability is analyzed. The main objective is to establish how the management of soil vulnerability in Metropolitan Lima and its relationship with urban sustainability will implement physical safety in our capital city, to finally reach conclusions and recommendations for a better culture of prevention against future disaster risks in Metropolitan Lima (Ramos, Esenarro et al., 2020).

\section{MATERIALS Y METHOD}

Due to the proposal to apply, verify and test the effectiveness of a Training Program on Disaster Risk Management Issues, which involves vulnerability, a "quasi-experimental" research design was applied, which corresponds to what is known as "design before and after with a non-randomized control group".

Both the Pre Test and the Post Test will be applied to the Experimental Group as well as to the Control Group, however the application of the Disaster Risk Management Training Program only to the Experimental Group, which will allow us to verify the effectiveness of the program directed to central government officials and municipalities to know the degree of knowledge and in this way to contribute to the reduction of the levels of the disaster risk according to the vulnerability of the soils of the capital city. Initially the Pre Test has the purpose of determining that both groups are similar or equivalent at the beginning of the application of the program. The Independent Variable, that is to say, the Training in Disaster Risk Management, will be applied only to the Experimental Group, therefore the Control Group will not be applied to this Program (Rodriguez et al., 2020).

The objective of the Post Test is to establish if there are significant differences between both groups at the end of the training program. If the Disaster Risk Management Training 
Program has been effective, there must be statistically significant differences between both groups in the Post-Test, which obviously must favour the experimental group. At the end of the application of the training program the Experimental Group will have to present a greater knowledge of the levels of risk, danger, vulnerability, resilience and environmental impact, related to the vulnerability of the soils of Lima. Finally, it is tried to determine, that if the Training Program in Disaster Risk Management is effective to obtain a reduction of the level of vulnerability of the soils of Lima and the relation with the urban sustainability. For the population where 180 people will be considered among officials and servants of the Metropolitan Municipality of Lima, of the districts of greater vulnerability of their soils and institutions of the central government that have to do with the vulnerability of our country.

Table 1. The distribution of the study population.

\begin{tabular}{|c|c|c|}
\hline $\mathbf{N}^{\circ}$ & Entities & $\mathbf{N}^{\circ}$ de Servers \\
\hline 1 & Central Government & 100 \\
\hline 2 & Metropolitan Municipality of Lima and District & 80 \\
\hline & Total & 180 \\
\hline
\end{tabular}

It will be formed by workers whose ages fluctuate between 25 and 55 years, being $55 \%$ of the masculine sex and 45\% feminine (see Table 1) (Esenarro et al., 2020).

Considering a non-probabilistic sampling of the criterion type, it is determined by applying criteria who will make up the experimental group and who will make up the control group.

Table 2. The distribution of the research design.

\begin{tabular}{|c|c|c|c|}
\hline Group & Central government & MM de Lima y Distritos & Total \\
\hline Experimental & 30 & 30 & 60 \\
\hline Control & 30 & 30 & 60 \\
\hline & & Total & 120 \\
\hline
\end{tabular}

Therefore, 120 workers from both the central and local governments are considered for the research sample, where 60 will belong to the experimental group and 60 to the control group, which is equivalent to $66.67 \%$ of the total population considered. (See Table 2).

\subsection{RESEARCH TECHNIQUES}

The main technique considered for this work are the surveys that were carried out in the state entities as well as to the general public. The same applies to the data on soil bearing 
capacities that are the subject of the research.

\subsection{DATA COLLECTION INSTRUMENTS}

The main instrument applied is a training program in disaster risk management aimed at workers of the Central Government and Regional Governments, which will be applied to the Experimental Group and will not be applied to the Control Group under consideration. (Esenarro et al., 2020).

As a contribution for greater knowledge in training topics related to vulnerability, the ones carried out by CENEPRED (2015).

\subsection{DATA PROCESSING AND ANALYSIS}

- It is considered an orderly sequence for obtaining the expected results.

- Collection of updated documentary and statistical information.

- Critical analysis of the documentation.

- Application of the Training on the National System of Disaster Risk Management (SINAGERD).

- Analysis of the results of the application of the SINAGERD training.

- Appropriate corrective measures.

- Approach of alternatives tending to improve the Risk Prevention Culture.

- Analysis of the results of the surveys

- Analysis of the results of soil bearing capacities.

- Regarding the statistical technique, descriptive statistics are applied considering measures of central tendency such as

- Mean, dispersion measures such as variance and standard deviation, use of tables and statistical histograms, among others. 
Trial pits:
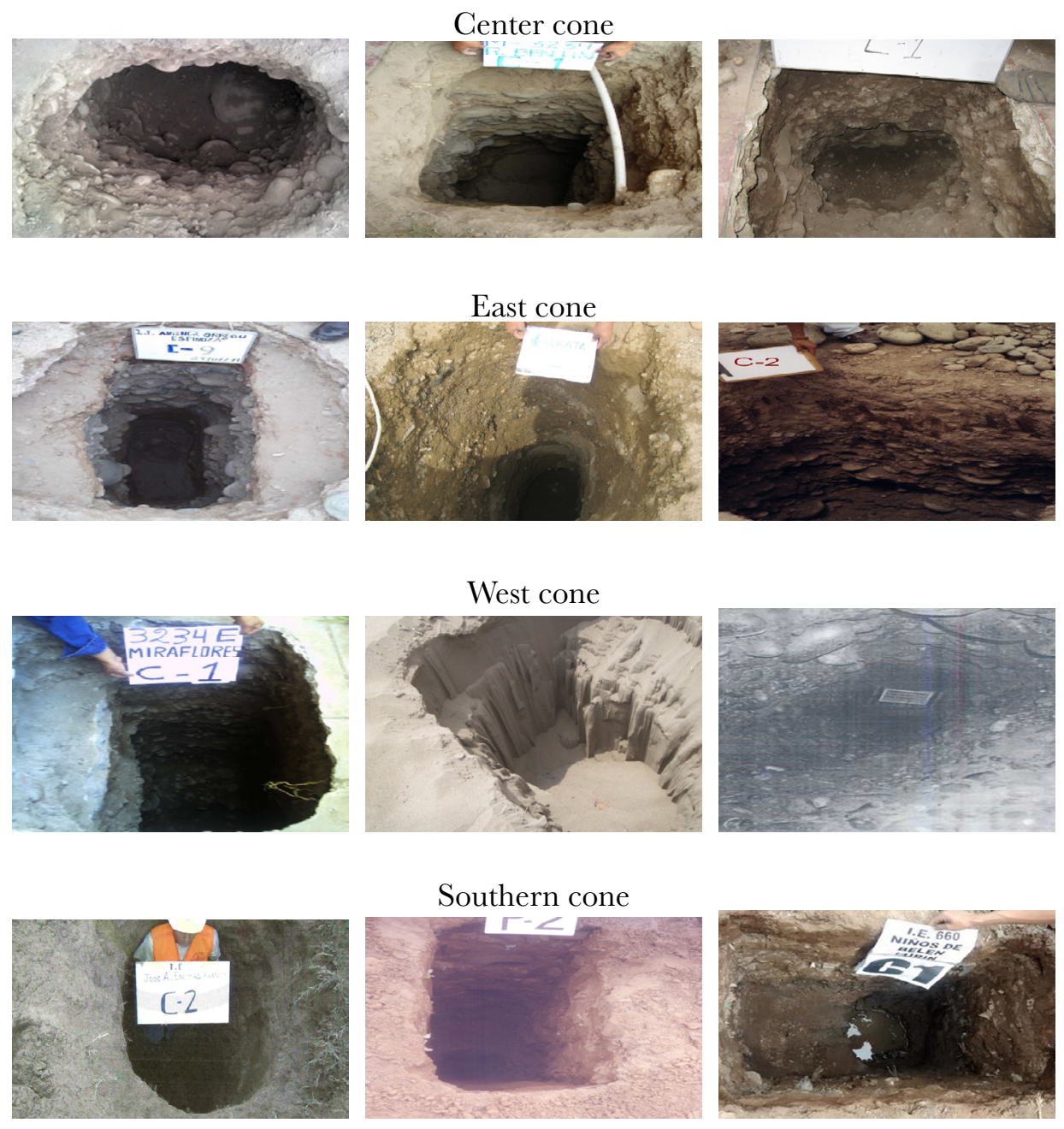

Figure 1. Trial pits of Metropolitan Lima.

In the Figure 1 it can see the photos with the different types of soil, which are found in the Lima cones. 


\section{RESULTS}

Elaboration of cartography of the study of the ground of Metropolitan Lima and its relationship with the urban sustainability (Guerra et al., 2020).

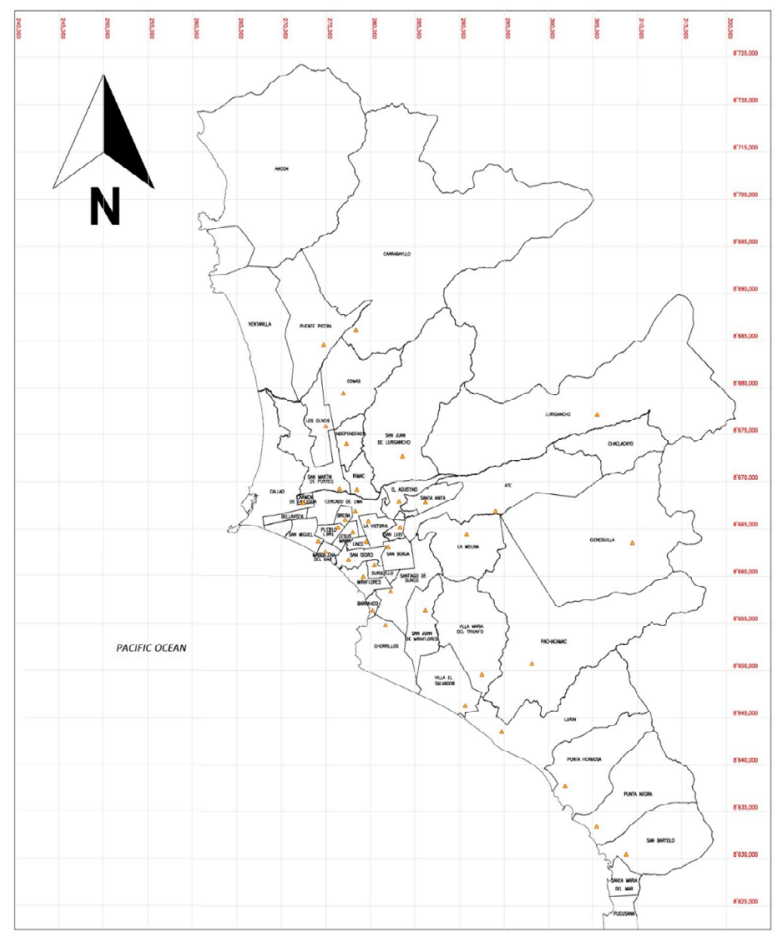

\begin{tabular}{|c|c|c|c|c|c|}
\hline \multirow{2}{*}{ Cone } & \multirow{2}{*}{ Calicata } & \multirow{2}{*}{ District } & \multicolumn{2}{|c|}{ Coordinate } & \multirow{2}{*}{$\begin{array}{l}\text { Portant } \\
\text { capacity } \\
\text { Kovema }\end{array}$} \\
\hline & & & North & Eats & \\
\hline \multirow{6}{*}{ North } & $c-1$ & San Martin de Porres & 8668684 & 273224 & 3.10 \\
\hline & $c-1$ & Independencia & 8671258 & 276904 & 0.70 \\
\hline & $c-1$ & Los Olivos & 8673334 & 273609 & 1.74 \\
\hline & $c-1$ & Comas & 8677708 & 276578 & 2.88 \\
\hline & $C-4$ & Puente Piedra & 8000561 & 288641 & 1.18 \\
\hline & $c-1$ & Carabayllo & 8685641 & 278438 & 1.08 \\
\hline \multirow{10}{*}{ Center } & $c-1$ & Cercado de Lima & 8686482 & 277795 & 4.00 \\
\hline & $c-1$ & Rimac & 8609338 & 278315 & 4.00 \\
\hline & $c-1$ & Breña & 8066721 & 277337 & 4.63 \\
\hline & c-1 & La Victoria & 8605202 & 280017 & 2.64 \\
\hline & c-1 & Lince & 8603230 & 279336 & 4.52 \\
\hline & $c-4$ & Jesús Maria & 8684074 & 277195 & 3.47 \\
\hline & $a-1$ & Pueblo Libre & 8005100.2 & 276364.6 & 4.00 \\
\hline & $c-20$ & San Borja & 8683070.97 & 281974.33 & 6.00 \\
\hline & $C-14$ & Surquillo & 8001204.16 & 280030.08 & 3.50 \\
\hline & $c-1$ & Surco & 8057887 & 281797 & 1.75 \\
\hline \multirow{7}{*}{ East } & $\infty$ & San Juan de Lurigancho & 8057291 & 276988 & 3.30 \\
\hline & $c-2$ & El Agustino & 8607883.38 & 283188.04 & 4.00 \\
\hline & $c-1$ & Santa Anita & 8051910.85 & 281435.2 & 4.12 \\
\hline & $c-1$ & La Molina & 8602819 & 289281 & 0.73 \\
\hline & c.5 & Ate & 8869345 & 301375 & 2.42 \\
\hline & c-1 & Lurigancho - Chosica & 8672483.38 & 285704 & 3.97 \\
\hline & $c-1$ & Cieneguilla & 8661656 & 300882 & 1.41 \\
\hline \multirow{6}{*}{ West } & $c-1$ & San Miguel & 8063650.74 & 274125.12 & 5.03 \\
\hline & $c-1$ & Magdalena & 8682729 & 274826 & 3,34 \\
\hline & $C-2$ & San Isidro & 8661680 & 277153 & 5.00 \\
\hline & c-1 & Miraflores & 8058602 & 281428 & 400 \\
\hline & $\infty$ & Barranco & 8065845 & 280332 & 1.80 \\
\hline & c-1 & Chorrillos & 8654767 & 281684 & 0.80 \\
\hline \multirow{7}{*}{ Southern } & $c-2$ & San Juan de Miraflores & 8056361 & 286149 & 1.44 \\
\hline & $a-6$ & Villamaria del Triunfo & 8649450.01 & 282134.74 & 1.85 \\
\hline & c-2 & Villa el Salvador & 8040235 & 290627 & 1.00 \\
\hline & $c-1$ & Pachacamac & 8050162.11 & 295201.53 & 1.78 \\
\hline & $c-1$ & Lurin & 8644465 & 290003 & 0.82 \\
\hline & $c-1$ & Punta Hermosa & 8635990 & 301549 & 1.16 \\
\hline & $c-1$ & San Bartolo & 8628667 & 300821 & 0.81 \\
\hline
\end{tabular}

\section{Legend}

\section{$\triangle \quad$ Calicata point \\ — District boundary}

Figure 2. Trial pit location in Metropolitan Lima.

Figure 2 shows the location of the pits that have been taken as study points, the points are also observed on the map. 


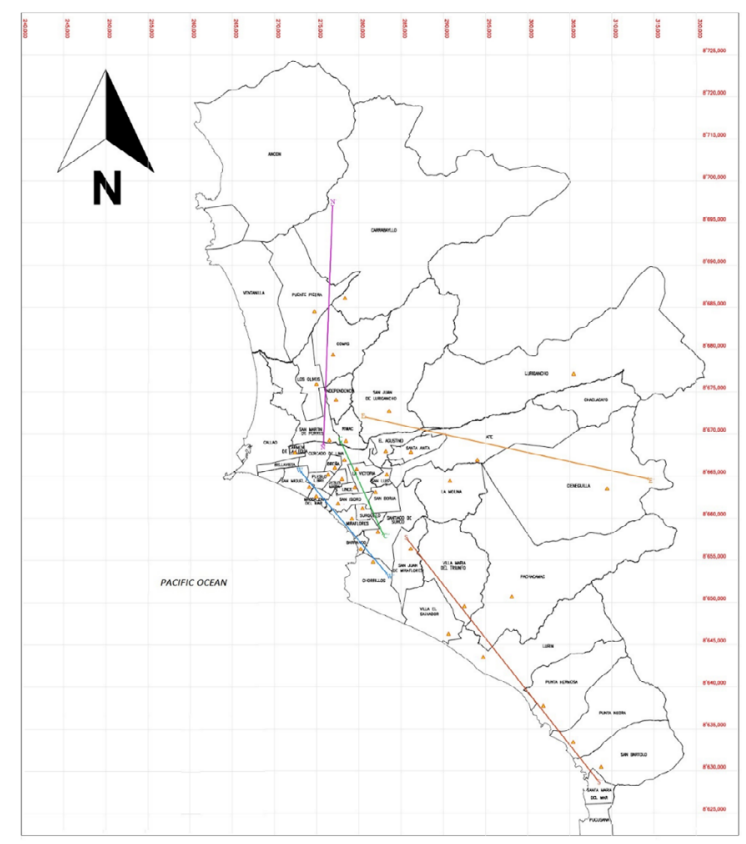

\begin{tabular}{|c|c|c|c|c|c|}
\hline \multirow{2}{*}{ Cone } & \multirow{2}{*}{ Calicata } & \multirow{2}{*}{ District } & \multicolumn{2}{|c|}{ Coordinate } & \multirow{2}{*}{$\begin{array}{l}\text { Portant } \\
\text { capacity } \\
\text { Kojom2 }\end{array}$} \\
\hline & & & North & Eats & \\
\hline \multirow{6}{*}{ North } & $c-1$ & San Martin de Porres & 8668684 & 273264 & 3.10 \\
\hline & $c-1$ & Independencia & 8671258 & 278904 & 0.70 \\
\hline & $c-1$ & Los Olivos & 8673334 & 273609 & 1.74 \\
\hline & $c-1$ & Comas & 8677708 & 276578 & 2.88 \\
\hline & $c 4$ & Puente Piedra & 8600561 & 288641 & 1.18 \\
\hline & $c-1$ & Carabayllo & 8685641 & 279438 & 1.08 \\
\hline \multirow{10}{*}{ Center } & $c-1$ & Cercado de Lima & 8606482 & 277795 & 4.00 \\
\hline & $c-1$ & Rimac & 8689338 & 278315 & 4.00 \\
\hline & $c-1$ & Breña & 8666721 & 277337 & 4.63 \\
\hline & $c-1$ & La Victoria & 8605202 & 280017 & 2.64 \\
\hline & $c-1$ & Lince & 8603230 & 279336 & 4.52 \\
\hline & $c-4$ & Jesús Maria & 8684074 & 277195 & 3.47 \\
\hline & $c-1$ & Pueblo Libre & 8085106.2 & 270364.6 & 4.00 \\
\hline & $c-20$ & San Borja & 8663070.97 & 281974.33 & 6.00 \\
\hline & C-14 & Surquillo & 8661204.16 & 280030.08 & 3.50 \\
\hline & $c-1$ & Surco & 8657887 & 281797 & 1.75 \\
\hline \multirow{7}{*}{ East } & $\infty$ & San Juan de Lurigancho & 8057291 & 278998 & 3.30 \\
\hline & $c-2$ & El Agustino & 8687883.38 & 283188.04 & 4.00 \\
\hline & $c-1$ & Santa Anita & $8 e 51910.85$ & 281435.2 & 4.12 \\
\hline & $c-1$ & La Molina & 8602819 & 289281 & 0.73 \\
\hline & $C .5$ & Ate & 8689345 & 301375 & 2.42 \\
\hline & $c-1$ & Lurigancho - Chosica & 8672483.38 & 295704 & 3.97 \\
\hline & $c-1$ & Cieneguilla & 8681658 & 300882 & 1.41 \\
\hline \multirow{6}{*}{ West } & $c-1$ & San Miguel & 8663850.74 & 274125.12 & 5.03 \\
\hline & $c-1$ & Magdalena & 8682729 & 274826 & 3,34 \\
\hline & $c-2$ & San Isidro & 8081680 & 277153 & 5.00 \\
\hline & $c-1$ & Miraflores & 8058602 & 281428 & 4.00 \\
\hline & $c-6$ & Barranco & 8655845 & 280332 & 1.80 \\
\hline & $c-1$ & Chorrillos & 8054767 & 281684 & 0.80 \\
\hline \multirow{7}{*}{ Southern } & $c-2$ & San Juan de Miraflores & 8056361 & 286149 & 1.44 \\
\hline & $c-6$ & Villamaria del Triunfo & 8649450.01 & 292134.74 & 1.85 \\
\hline & $c-2$ & Villa el Salvador & 8646235 & 290627 & 1.00 \\
\hline & c-1 & Pachacamac & 8659162.11 & 295991.53 & 1.79 \\
\hline & $c-1$ & Lurin & 8644465 & 296083 & 0.82 \\
\hline & $c-1$ & Punta Hermosa & 8635990 & 301549 & 1.16 \\
\hline & $c-1$ & San Bartolo & 8629667 & 306821 & 0.81 \\
\hline
\end{tabular}

\section{Legend}

$\Delta \quad$ Calicata point

- District boundary

- North cone section line

- Center cone section line

- East cone section line

- Center west cone section line

\section{- Southern cone section line}

Figure 3. Cross section of Trial pits in Metropolitan Lima opia. 
Figure 3 shows the location of the holes identified with their respective colors and reference points as well as north, east, south and west, as can be seen in the graph, Zoning according to soil bearing capacity of Metropolitan Lima.

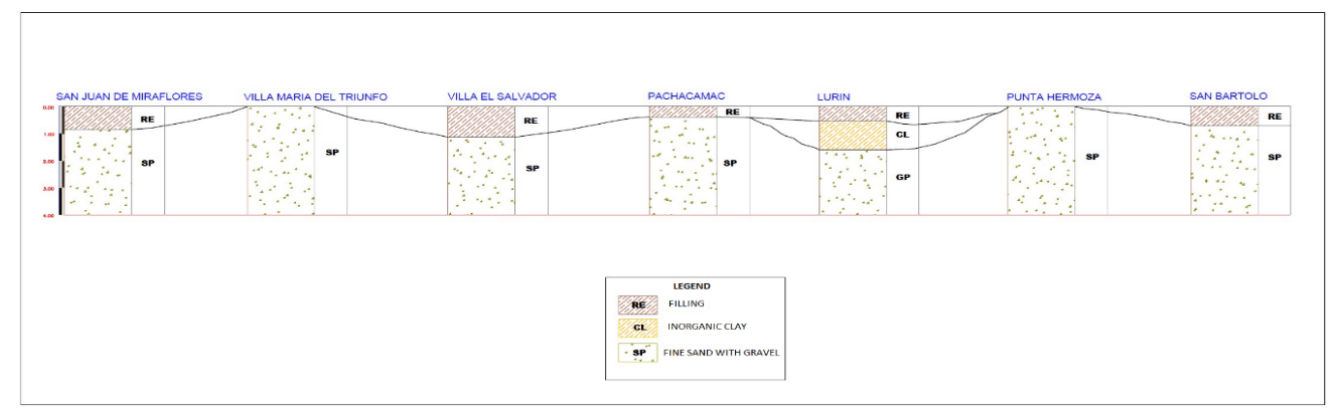

Figure 4. Soil profile south cone N-N'.

The Figure 4 shows the profile of the soil in the area of the south cono N-N.

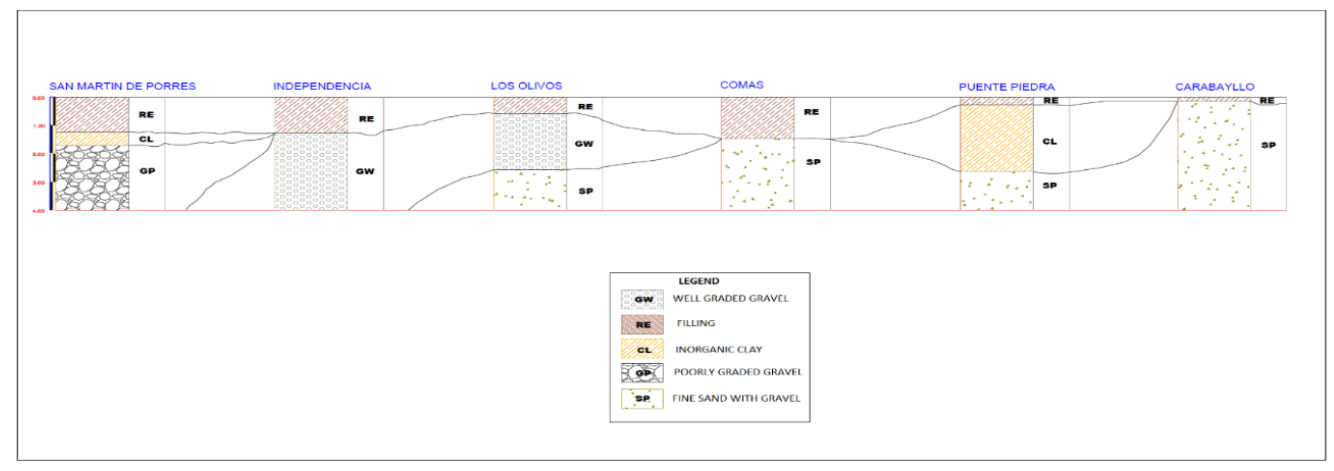

Figure 5. Soil profile north cone N-N'.

The Figure 5 shows the profile of the soil in the area of the north cono N-N.

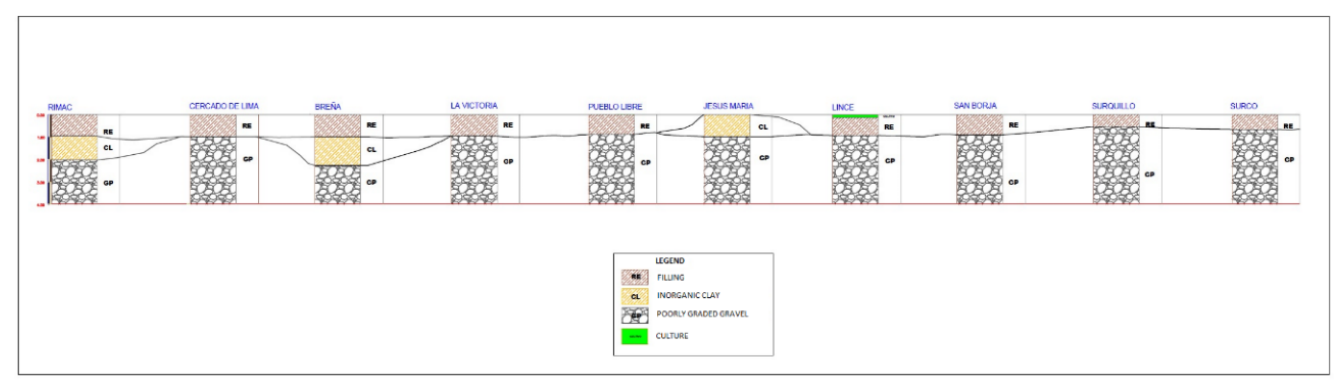

Figure 6. Soil profile cone C-C' Center.

The Figure 6 shows the profile of the soil in the area of the center cono C-C. 


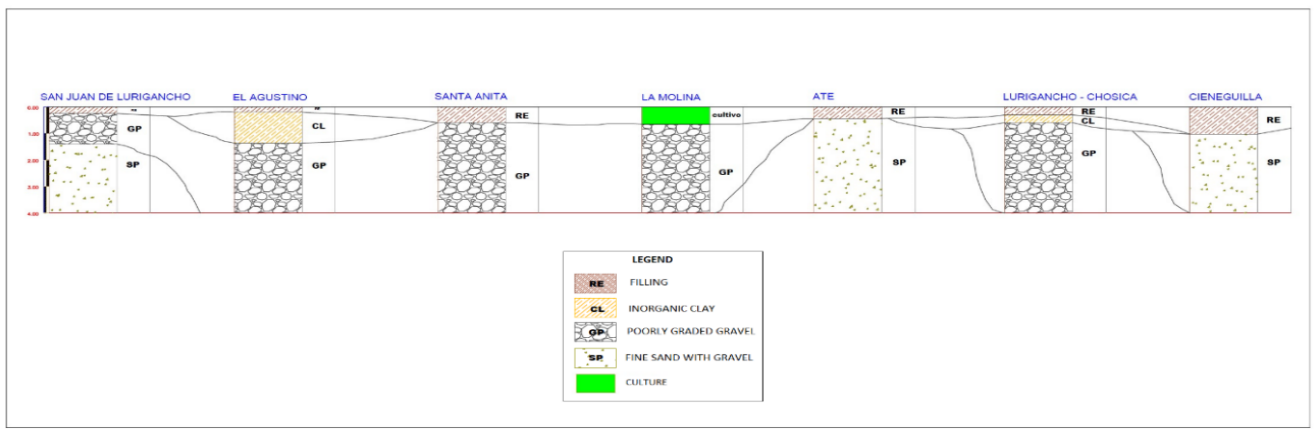

Figure 7. W-W' West Cone Soil Profile.

The Figure 7 shows the profile of the soil in the area of the West Soil profile.

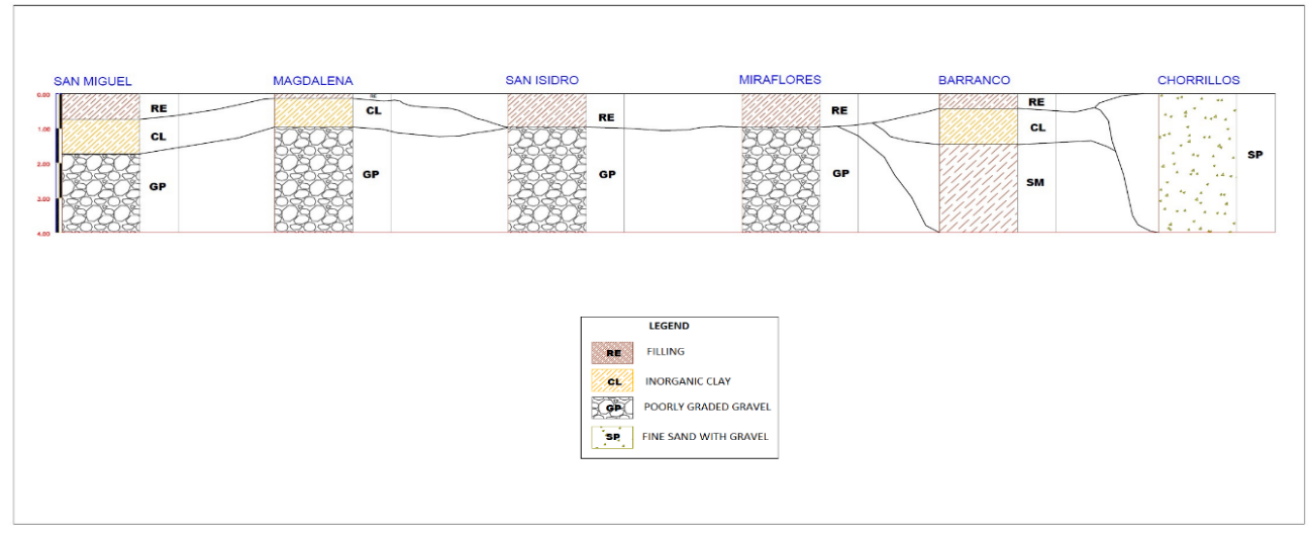

Figure 8. Soil profile north cone N-N'.

The Figure 8 shows the profile of the soil in the area of the north cono N-N.
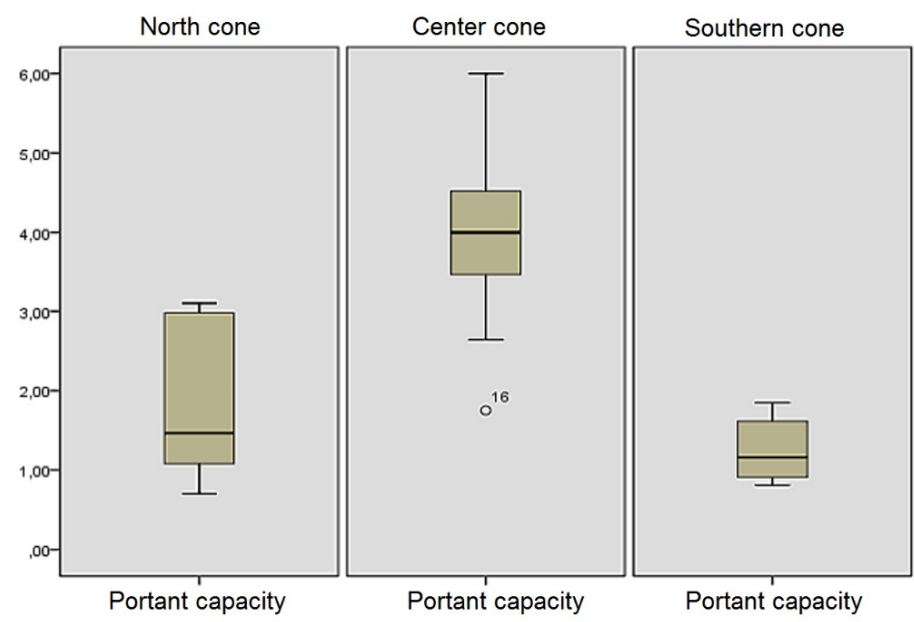

Figure 9. Anova test. (Bearing capacity $=\mathrm{Kg} / \mathrm{cm}^{2}$ ). 
In the Figure 9 The anova test (statistical) was used to compare the means of the bearing capacity of the soils of the northern, central and southern cone. it is the one that concludes that the means of the north and south cone are statistically equal. on the contrary, the mean of the center cone turned out to be significantly higher, which is observed in the bar graph.

With the results obtained with the studies of Mechanics of Soils, the Map of Zoning of Soils according to Bearing Capacity has been elaborated - Metropolitan Lima, where districts have been grouped by cones and considered a general classification of the soils that are included from very good, good, regular, bad and very bad, according to the average values of bearing capacity obtained of the districts matter of the investigation. For the purpose of preparing the Zoning Map, Table 4 has been considered, which presents a range of referential values of Soil Bearing Capacity.

Table 4. Comparison of the level of knowledge in the control group and the experimental group at the beginning of the experiment (pre-test) for resilience Test of independent samples.

\begin{tabular}{|c|c|c|c|c|c|}
\hline Pre-test & F & Sig. & $\mathbf{t}$ & $\begin{array}{c}\text { Test T } \\
\text { gl }\end{array}$ & $\begin{array}{c}\text { Sig. } \\
\text { (bilateral) }\end{array}$ \\
\hline Equal variance has been assumed &, 006 &, 938 &,- 119 & 118 &, 905 \\
\hline Equal variance has not been assumed & 0 & 0 &,- 119 & 117,604 &, 905 \\
\hline
\end{tabular}

The results of soil profiles grouped at the level of 5 cones, after their interpretation, show us the stratigraphic sequence, being the districts of the central cone those that have mostly gravelly soils which indicate us to be good soils for foundation purposes, with respect to the northern cone and the southern cone that have mostly sandy soils of less stability.

\section{DISCUSSION}

The present research, in accordance with the application of the Training Program in DRM, which involves vulnerability, seeks to contribute to the knowledge in matters of risk prevention culture, and to promote the active participation of the organizations involved in safety issues in the face of events that cause disasters in our capital city, which, despite some not being predictable, can be mitigated and reduce the risks of disasters. In order to face the problem, it is necessary to have an integral and multidisciplinary coordination and participation of all the sectors of the state and private institutions (Chu et al., 2020). 
At present, there are several institutions that carry out research studies related to vulnerability, hazards and risks, whose information is widely dispersed and there is no specific data bank that articulates them, which is considered a future task to incorporate research sources to an institution or central entity where information is available to all stakeholders. Likewise, there are institutions whose specific function is disaster preparedness and rapid response with the main task of saving lives. Therefore, the importance of political will and commitment of those who lead the institutions must be kept in mind. In addition, they are necessary for the implementation and enforcement of regulations in an effective and timely manner since citizens living not only in Metropolitan Lima. But throughout our territory, have the peace of mind and security that we are prepared to respond to a future disaster (Ascue et al., 2020).

The research shows very important results with respect to vulnerability, where the value can be observed $(\mathrm{Sig}=0.00<0.05)$ and it can be said that the Experimental Group (to which the training program was applied), showed a higher level of knowledge in vulnerability than the control group (to which the training program was not applied), those before and after the experiment remain statistically the same. That is, after two years of applying the training program to the experimental group, they are better prepared in knowledge. The significant difference allows us to reject the Null Hypothesis H0, therefore the Alternative Hypothesis $\mathrm{H} 1$ is accepted, with a confidence level of 95\%, considered in the proposed research (Lohani et al., 2020).

The surveys to the general population of our capital city have determined the little knowledge in risk, danger and vulnerability issues, so $83 \%$ responded that a greater education is required from the institutions and organisms responsible in the fulfillment of the norms of the Law of the National System of Management of the Disaster Risk, since these do not fulfill their functions, at the moment there is very little progress in training on these subjects being a main problem of security in our city the lack of conscience and culture of prevention to face the future events that cause disasters in our city.

In 2010 the Geophysical Institute of Peru - IGP, conducted the study "Seismotectonic Zoning for 7 districts of Metropolitan Lima" (Pucusana, Santa Maria, San Bartolo, Punta Negra, Punta Hermosa, Santa Rosa and El Agustino), in order to obtain results from the dynamic behavior of the soil for the seismic part and the soil analysis for the geotechnical 
part, following the procedure provided by CISMID in the "Study of Vulnerability and Earthquake Risk in 42 districts of Lima and Callao". Making the comparison with the present research work, 36 districts are being considered from which their soil analysis and the consequent classification and bearing capacity of the soils for foundation purposes have been made, in order to determine the level of vulnerability of the soils of the districts, grouping them by cones according to their geographical location and better approach for their interpretation, which allows to indicate that in spite of the existing risks, the central cone of Lima is the one with the lowest degree of vulnerability according to the results of soil bearing capacity.

\section{CONCLUSIONS}

The results of the application of the training program in disaster risk management, to public officials, show us a Sig in the experimental group is 0.00, less than 0.05, and it can be concluded that the risk in terms of the score in the experimental group is directly and significantly related to urban sustainability in terms of knowledge.

To compare the means of soil bearing capacity in the northern, central and southern cones, we used the ANOVA test and as a complement the Tukey test, which allowed us to conclude that the means in the northern and southern cones are statistically equal. On the contrary, the mean for the central cone was significantly higher than the other two cones, which can be seen in Figure 10. Therefore, it can also be concluded that the soils of the central cone are better than the soils of the northern and southern cones, which are from regular too bad, respectively.

Surveys of public servants allowed us to determine that only $55 \%$ of them are aware of the meaning of risk and vulnerability, therefore $45 \%$ are totally unaware of these terms. Likewise, surveys to the general public about the lack of prevention culture, $83 \%$ indicated that yes, hence the need to apply a course or training on disaster risk management issues at all levels of education.

The dangers or hazards in Metropolitan Lima are extremely complex, mainly earthquakes, huaycos, floods and others, which affect the physical, social and economic environment of our capital city according to the degree of vulnerability. Therefore, in order to achieve a 
resilient capital and to face adverse events, a greater knowledge of the physical reality of our city is required. This allows us to respond in a timely manner to the occurrence of any disaster or emergency.

\section{REFERENCES}

Alvarado, K., Esenarro, D., Rodriguez, C., \& Vasquez, W. (2020). Lemna minor influence in the treatment of organic pollution of the industrial effluents. $3 C$ Tecnología. Glosas de innovación aplicadas a la pyme, 9(3), 77-97. https://www.3ciencias. com/wp-content/uploads/2020/09/art-4-3c-tecno-ed.-35-vol.-9-n.-3-1.pdf

Ascue,J. C., Esenarro, D., Rodriguez, C., Tafur, I., \& Vázquez, W. (2020). Geological Vulnerability of the Fragile Ecosystem Case: Huancaro-District of Santiago MicroBasin - Cusco. Fournal of Green Engineering, 10(6), 2746-2761. http://www.jgenng. com/volume10-issue6.php

Centro Nacional de Estimación, Prevención y Reducción del Riesgo de Desastres (GENEPRED). (2015). Manual para la evaluación de riesgos originados por fenómenos naturales. 02 Versión. http://www.cenepred.gob.pe/web/wp-content/ uploads/Guia_Manuales/Manual-Evaluacion-de-Riesgos_v2.pdf

Ghu, H., Gao, G.-F., Ma, Y., Fan, K., \& Delgado-Baquerizo, M. (2020). Soil Microbial Biogeography in a Changing World: Recent Advances and Future Perspectives. mSystems, 5(2). https://doi.org/10.1128/mSystems.00803-19

Esenarro, D., Escate, I., Anco, L., Tassara, G., \& Rodriguez, G. (2020). Proposal for an Ecological Research Center for the Recovery and Revaluation of Biodiversity in the Town of Quichas-Lima, Peru. International Journal of Environmental Science and Development, 11(4), 212-216. https://doi.org/10.18178

Esenarro, D., Rodriguez, C., Huachaca, K., Cachay, B., \& Aylas, C. (2020). Classification and Characterization of the Sustainable Wetland Bello Horizonte Test Engineering \& Management, 13453 - 13458. 
Guerra, G. A., Rosa, I. M. D., Valentini, E., Wolf, F., Filipponi, F., Karger, D. N., \& Xuan, A. (2020). Global vulnerability of soil ecosystems to erosion. Landscape Ecology, 35, 823-842. https://doi.org/10.1007/s10980-020-00984-z

Lohani, S., Baffaut, C., Thompson, A. L., Aryal, N., Bingner, R., Bjorneberg, D. L., Bosch, D., Bryant, R., Buda, A., Dabney, S. M., Davis, A. R., Duriancik, L. F., James, D., King, K., Kleinman, P., Locke, M., McCarty, G. W., Pease, L., Reba, M., ... \& Yasarer, L. (2020). Performance of the Soil Vulnerability Index with respect to slope, digital elevation model resolution, and hydrologic soil group. Fournal of Soil and Water Conservation, 75(1), 12-27. https://doi.org/10.2489/ jswc.75.1.12

Ramos, L., Esenarro, D., Rodriguez, C., \& Lagos, J. (2020). Recovery of public spaces for the conservation of green areas in Tablada Lurin. In IOP Conference Series: Materials Science and Engineering, Volume 910, 3rd International Conference on Civil Engineering and Architecture (ICCEA 2020). Compiègne, France. https://doi.org/10.1088/1757899X/910/1/012020

Rodriguez, C., Esenarro, D., Corimanya, P., Flores, F., Aylas, G., \& Lagos, J. (2020). Proposal for a Sustainable Infrastructure Design (Ecolodge) in Quichas Town, Perú. Test Engineering \& Management, 9250 - 9256. 
3C Tecnología. Glosas de innovación aplicadas a la pyme. ISSN: 2254 - 4143 Edición Especial Special Issue Noviembre 2020 